\title{
7. X-RAY MINERALOGY AND GEOCHEMICAL STUDIES OF SEDIMENTS, LEG 125 SITES 781 THROUGH 784 AND $786^{1}$
}

\author{
Dietrich Heling, ${ }^{2}$ Alexander Schwarz, ${ }^{2}$ and Dieter Garbe-Schönberg ${ }^{3}$
}

\begin{abstract}
The mineral composition of clay $(<2 \mu \mathrm{m})$ - and silt $(<63 \mu \mathrm{m})$-fractions from sediments sampled at Sites 781 through 784 and 786 from the Mariana and Izu-Bonin forearcs (ODP Leg 125), were investigated by X-ray diffraction analysis. The concentrations of major and trace elements of selected samples were determined by X-ray fluorescence analyses and the rare earth elements by ICP mass spectrometry.

The clay-fraction in the upper parts of all drilled sites consists predominantly of smectite and minor amounts of illite, kaolinite, and chlorite. The smectite is an Fe-rich, Al-poor beidellite having varying abundances of light rare earth elements (REE). Smectites which are enriched in cerium are probably detrital, those which are depleted are probably partly hydrogenous.

The mixed occurrence of the two different kinds of smectites at Site 784 has been interpreted as reflecting the varying proportions of the detrital and authigenic components of these sediments. At Site 782 and Hole 786A, authigenic smectites were found near an underlying basalt. They occur together with zeolites and palygorskite and are significantly depleted in cerium. These smectites may readily have formed of constituents dissolved from volcanic glass, whereas at Site 784 silica probably was supplied partly by the dissolution of radiolarians and diatoms. The bulk of smectite authigenesis is supposed to have happened on the seafloor.

At Hole 786B authigenic smectites were found together with clinoptilolite. The smectite is an $\mathrm{Fe}$ - and $\mathrm{Mg}$-rich beidellite. The shale-normalized REE profiles show heavy depletion of the light rare earth elements but no Ce deficiency with respect to La, $\mathrm{Pr}$ and Nd. At the same site a nearly pure sepiolite was found. The chondrite-normalized REE profile displays a significant, positive europium anomaly but is depleted with respect to all other rare earth elements.

Post-burial mineral neoformations or transformations were not observed in any of the sections, probably because these sediments were recovered from shallow-depth ranges, where temperatures are too low to cause reactions among minerals and pore solutions.
\end{abstract}

\section{METHODS \\ Preparation}

The $<2-\mu \mathrm{m}$-fraction was separated from the bulk sample by sedimentation techniques (Fig. 1). Salts diluted in the interstitial water were removed by dialysis for at least $24 \mathrm{hr}$, until the electric conductivity was reduced to $<10 \mu \mathrm{S}$. The carbonate content was determined gasometrically according to the method of Müller and Gastner (1971). Clay minerals were identified by XRD-analysis of oriented specimens prepared by pipetting some drops of a clay-in-water suspension to dry on an even glass slide at room temperature. To identify non-clay minerals and their abundance, non-oriented specimens were prepared by filling the powdered sample into a rectangular sample holder of 1 $\mathrm{cm}^{3}$ volume.

\section{X-ray Diffraction Analysis}

XRD-analyses were performed using a Siemens XRD 500 automatic diffractometer having $\mathrm{Ni}$-filtered $\mathrm{Cu}-\mathrm{K}$-alpha-radiation. In routine runs the following 2-theta ranges were used at a scanning speed of $1 \% \mathrm{~min}$.

Non-oriented bulk sample $2^{\circ}-70^{\circ}$

Non-oriented clay $(<2 \mu \mathrm{m}) 2^{\circ}-70^{\circ}$

Oriented clay, air dry $1^{\circ}-40^{\circ}$

Oriented clay, glycolated $1^{\circ}-30^{\circ}$

Oriented clay, heated $1^{\circ}-20^{\circ}$

Slower scanning speeds and different scanning ranges were employed when more precise d-values were demanded.

\footnotetext{
'Fryer, P., Pearce, J. A., Stokking, L. B., et al., 1992. Proc. ODP, Sci. Results, 125 College Station, TX (Ocean Drilling Program).

2 Institut für Sedimentforschung, INF236, 6900 Heidelberg, Federal Republic of Germany.

${ }^{3}$ Geologisches-Paläontologisches Institut, Universität Kiel, Olshausenstr. 40, D2300 , Kiel, Federal Republic of Germany.
}

The identification of the various minerals was aided through the Siemens application software DIFFRAC 11, which allows comparison of X-ray scans directly with data files from the International Centre for Diffraction Data (ICDD).

Semi-quantitative estimation of the abundances of the clays were based on the peak areas of basal reflections of oriented and glycolated samples. The abundances were recalculated so that the sum of all identified components totalled $100 \%$.

Quartz and feldspars were determined semiquantitatively by comparison of the peak heights of the $\{100\}$ - and $\{002\}$ - peaks respectively with corresponding standards. Amorphous compounds were estimated relatively by the rise of the XRD pattern above the baseline in the range between $20^{\circ}$ and $30^{\circ} 2$-theta, and are expressed by counts per second (cps).

\section{X-ray Fluorescence Analyses}

Chemical analysis of the major-element and trace-element concentrations of selected clay fractions were performed, using a Siemens wavelength-dispersive, sequential X-ray fluorescence spectrometer, model SRS 300 . The samples were melt with lithiumtetraborate (Spectromelt A 1000) in the proportion of 1:5.

Because of the very small quantities of sample matter, both the major-element and the trace-element concentrations were measured using melt-tablets. For the calibration curves, 35 standards were used.

Often the sample matter left over was insufficient to determine the loss of ignition (LOI). When possible, LOI was determined between $105^{\circ} \mathrm{C}$ and $1050^{\circ} \mathrm{C}$.

\section{Mass Spectrometry}

The determination of rare earth elements was performed on a induced coupled plasma mass spectrometer (ICP-MS), model VG Plasma Quad (PQ1). Samples were dissolved under pressure with suprapure concentrated acids ( $\mathrm{HF}$, aqua regia) at a temperature of $160^{\circ} \mathrm{C}$. 


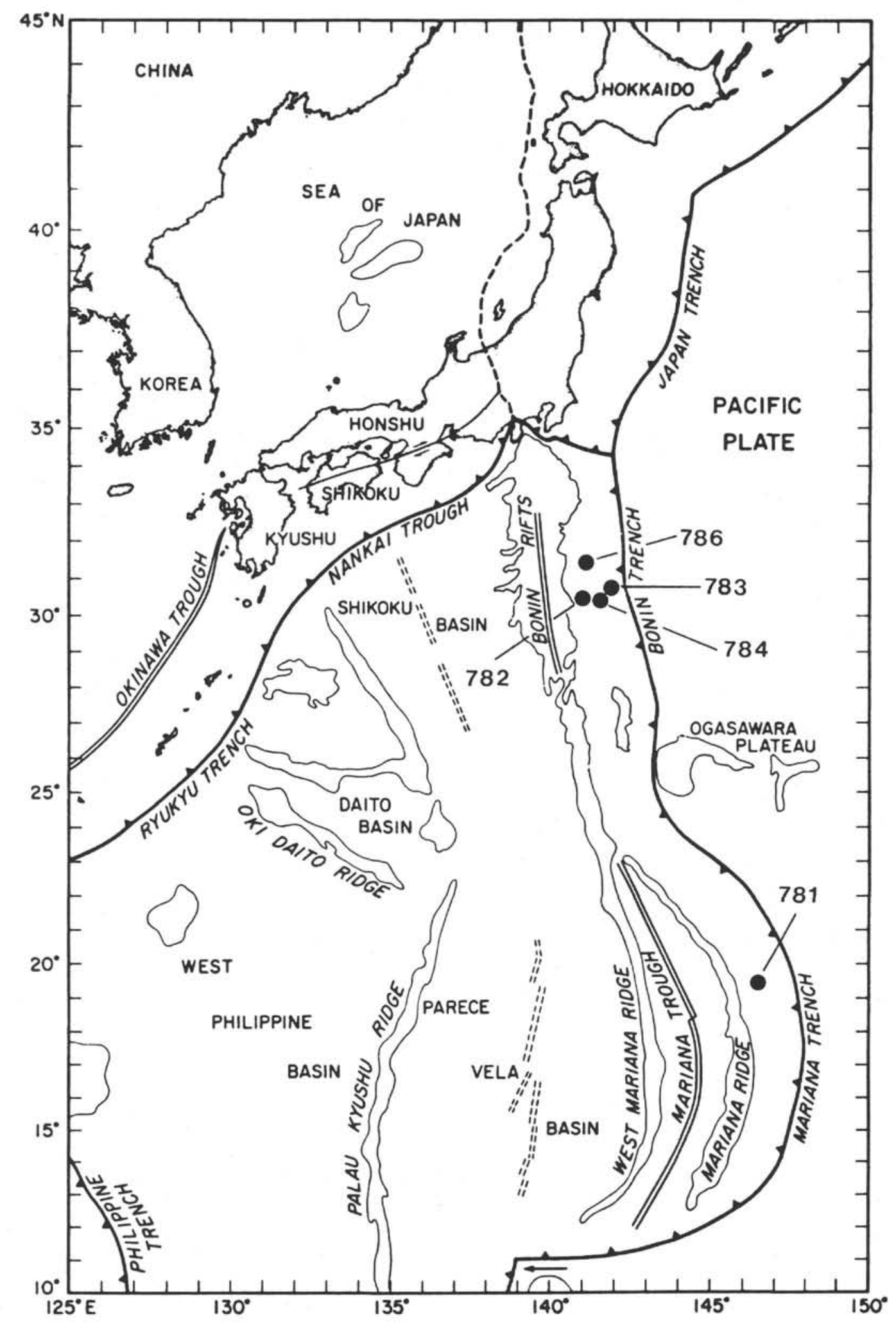

Figure 1. Location map. 


\section{Results}

\section{Mineralogy}

Clay minerals were recognized in general by their basal reflections from oriented, glycolated, and heated samples. The various non-clay minerals were detected by their most prominent reflections, unless these did not interfere with those of other minerals present.

The following specific minerals were detected:

Smectites are the most common clay minerals in the drilled sites. Different types of smectites were observed. Some have reduced basal spacings of $12.5 \AA-13.5 \AA$ (air dry) and display high swelling up to $17.5 \AA$ with ethylene glycol (Fig. 2). These smectites always have sharp 001 reflections, which indicates a high crystallographic order.

Other smectites have basal spacings of $13.8 \AA-14.8 \AA$ (air dry) and swell to approximately $17 \AA$ in ethylene glycol (Fig. 3). These smectites always have a broad and unsharp 001 reflection. The first occurs in the deepest units of Sites 781, 782, and 784 and Hole 786A, as well as in Hole 786B at a depth of $750 \mathrm{mbsf}$ (Fig. 4). The second represents the major component of the clay fraction in all other drilled sections.
Illites are very common in the drilled sections and always occur together with kaolinite and chlorite. At Sites 781 and 782 and Hole $786 \mathrm{~A}$, all these three minerals are absent in the deeper sections.

Chlorites are present in small amounts and display reflections, typically for Fe-rich chlorites.

Kaolinite is mostly present in small amounts but always exceeds the abundance of chlorite. Kaolinite was distinguished from chlorite by their 002 and 004 reflections respectively at $3.58 \AA$ and $3.54 \AA$.

Palygorskite occurs as a pale red mineral in two horizons at Site 782 and was recognized by its basal reflection at $10.6 \AA$ (Fig. 5). Treatment with ethylene glycol was not followed by expansion. In diffractograms of non-oriented samples most of the expected reflections are clearly detectable.

Sepiolite occurs at Hole $786 \mathrm{~B}$ as a pink mineral interlayered between a basalt flow and an underlying dacite breccia. It was recognized by its strong peaks at $12.20 \AA$.

Quartz occurs frequently but in small amounts and is absent in places where smectite occurs together with zeolites and palygorskite.

Plagioclase is abundant in all drilled sites and was recognized by its peaks between $3.19 \AA$ and $3.16 \AA$. K-feldspars were not observed.

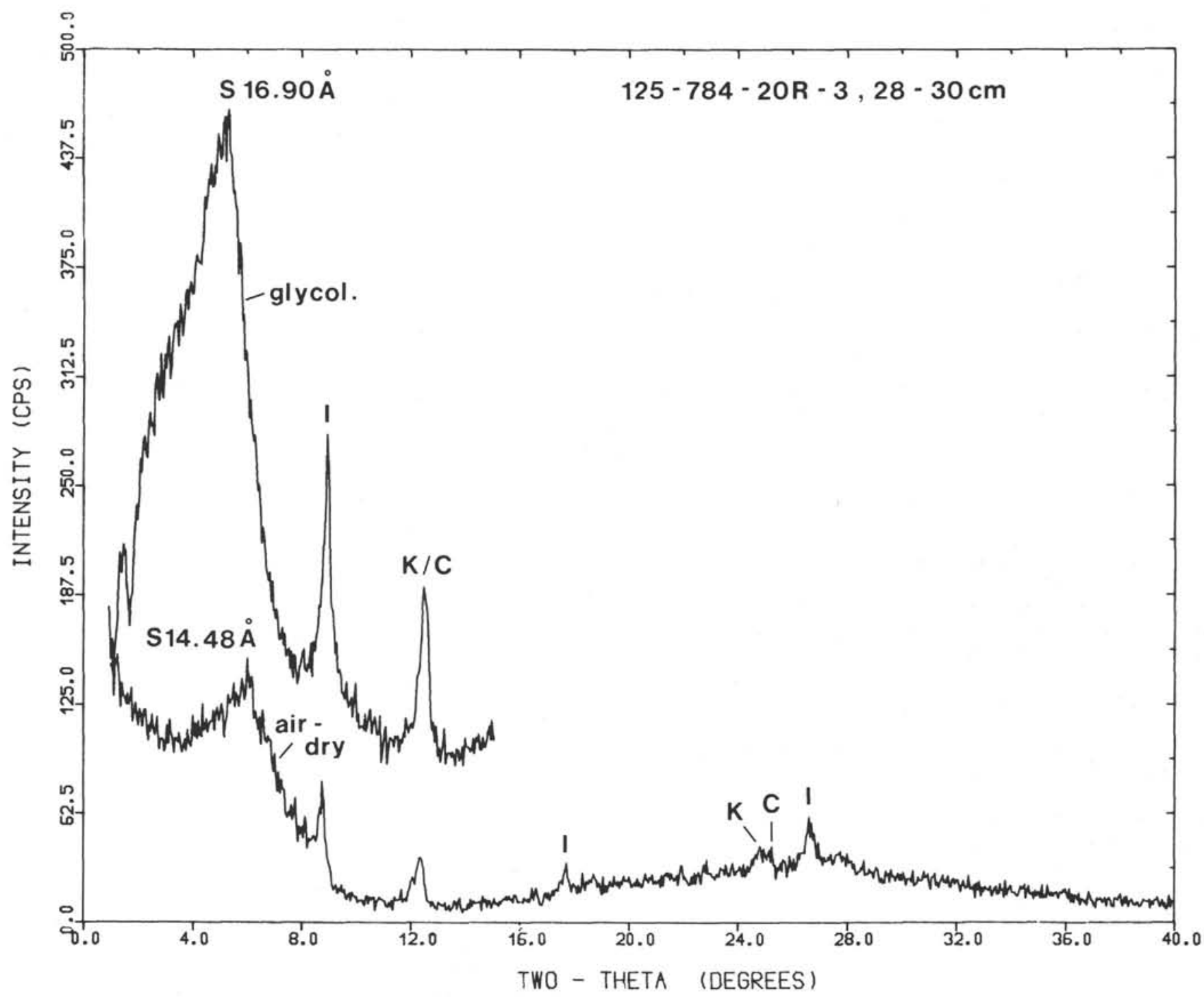

Figure 2. XRD patterns of a poorly crystallized smectite, Site 784 , Subunit IB, 178.0 mbsf. $S=$ smectite, $\mathrm{I}=$ illite, $\mathrm{K}=$ kaolinite, $\mathrm{C}=$ chlorite, $\mathrm{P}=$ palygorskite. 


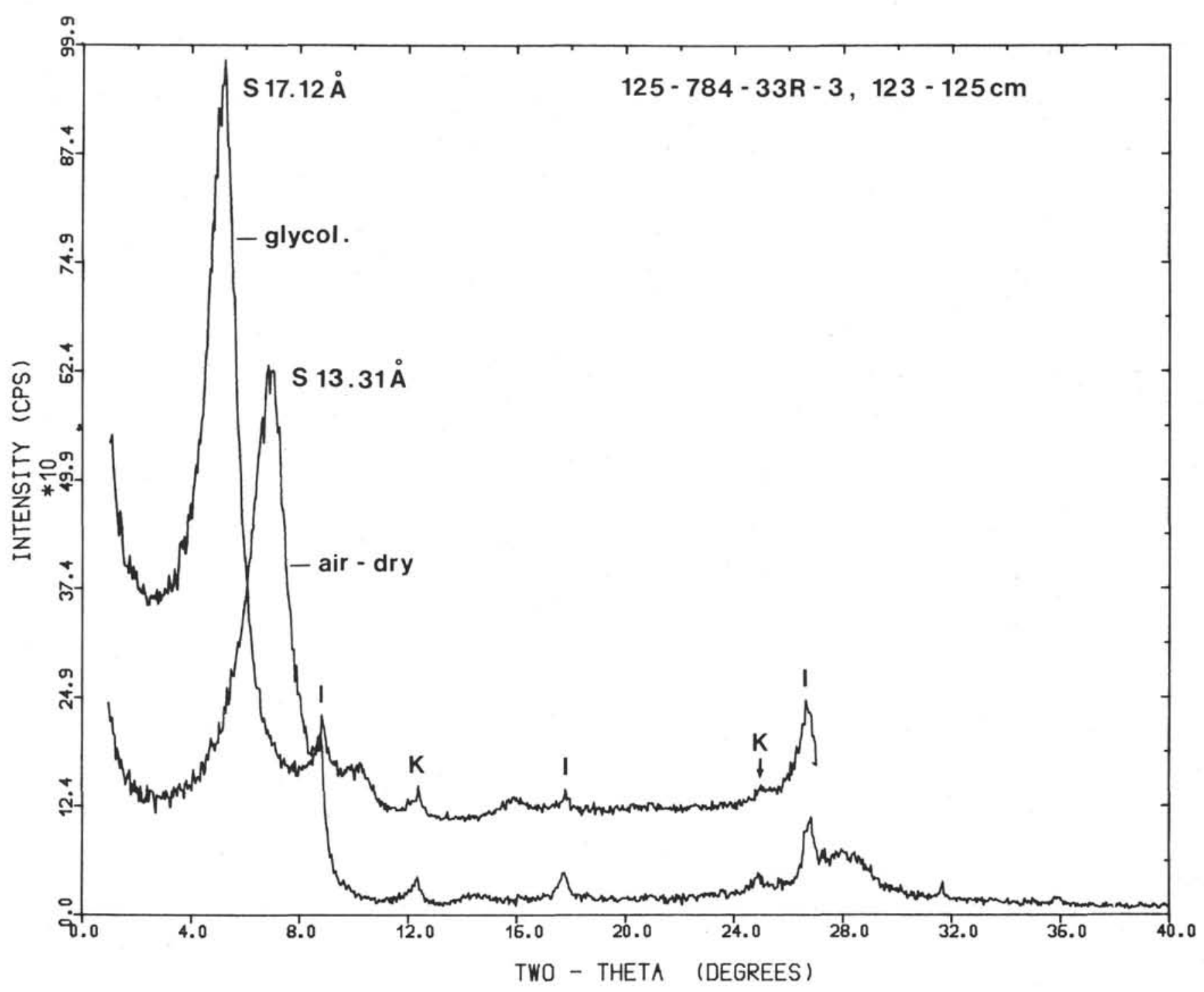

Figure 3. XRD patterns of a well-crystallized smectite, Site 784, Subunit IC, 304.2 mbsf.

Clinopyroxene is rare and could only be detected in the coarser fractions, after the separation of magnetite.

Magnetite occurs frequently, especially together with volcanic ash-layers and was identified by its prominent reflection at $2.53 \AA$, as well as its magnetic properties.

Phillipsite occurs in samples at Site 782 and Hole 786A together with palygorskite and smectite and was recognized by its strong reflection at $7.20 \AA$.

Clinoptilolite occurs together with smectite at Hole 786B and was recognized by its reflection at $8.95 \AA$.

Calcite is the major component of the sediments of Site 782 and Hole 786A. The sediments of all the other drilled sites are very low in carbonate. Calcite was detected by its major reflection at $3.03 \AA$ and with the aid of the carbonate bomb.

\section{DESCRIPTION OF SITES}

\section{Site 781}

Site 781 is located on the lowermost flank of Conical Seamount about $7 \mathrm{nmi}$ northwest of its summit. One lithostratigraphic unit, divided into three subunits, was defined:

\section{Unit I}

IA $\quad 0-72.32$ mbsf: Diatom-radiolarian silty clay grading downward into vitric silty clay and vitric clayey silt

IB $\quad 72.32-91.80 \mathrm{mbsf}:$ Vesicular, porphyritic basalt

IC 91.8-250.00 mbsf: Vitric silty clay and vitric clayey silt

\section{Mineralogical Composition}

The mineralogical composition of both the $<2-\mu \mathrm{m}$-fraction and the bulk sediment is shown graphically in Figure 6 . The $<2$ - $\mu \mathrm{m}$-fraction consists of $70 \%-100 \%$ smectite, $0 \%-20 \%$ illite, and $0 \%-20 \%$ kaolinite and chlorite. Compared to the abundance of kaolinite, chlorite is only present in small amounts. Shape and the low intensities of the uneven numbered basal reflections indicate a Fe-chlorite.

The smectite, which occurs all over the stratigraphic column, is of poor crystallinity, with the exception of three samples in subunit IC.

The bulk sediment is composed of $0 \%-1 \%$ quartz, $5 \%-25 \%$ feldspars, traces of clinopyroxene and magnetite, and a maximum of $20 \%$ calcite. In addition, the samples contain considerable quantities of X-ray amorphous matter. 


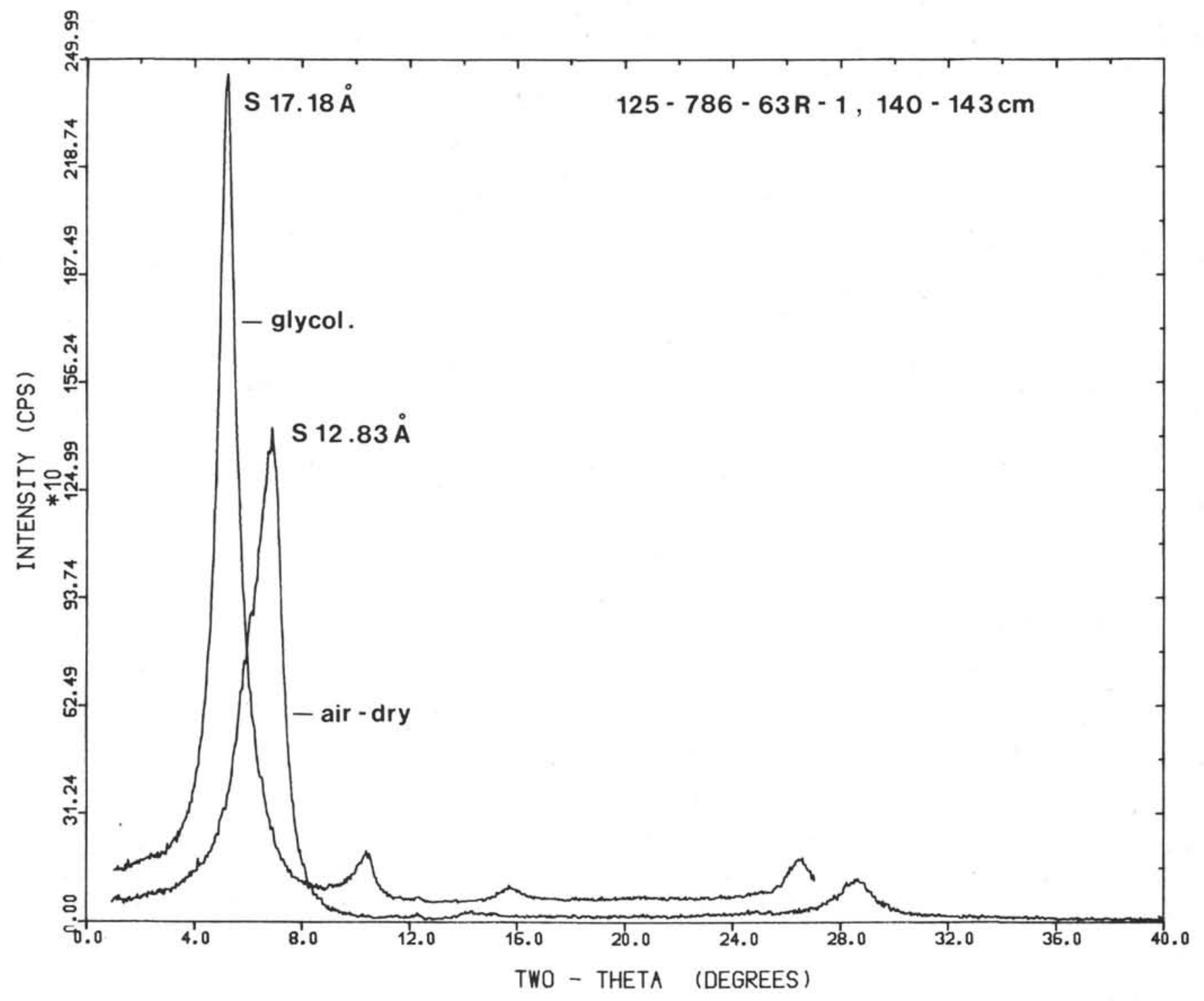

Figure 4. XRD patterns of a pure, extremely well-crystallized smectite, Hole 786B, Unit 25, 750.0 mbsf.

The color of the sediments varies between dark gray and light beige.

No chemical analyses were performed on samples of Site 781.

\section{Site 782}

Site 782 is located on the eastern margin of the Izu-Bonin forearc basin about halfway between the active volcanic arc and the trench.

The section was divided into the following lithostratigraphic units:

Unit I

IA $0-153.6$ mbsf: Gray to yellow-greenish nannofossil marl containing scattered volcanic debris and volcanic ash layers

IB 153.6-337.0 mbsf: Light to dark gray nannofossil marl containing scattered volcanic debris and volcanic ash layers

IC 337.0-409.2 mbsf: Vitric nannofossil chalk intercalated with tuffaceous sediment and pebble-rich sands, gravelly conglomerates, and ash layers
Unit II

409.2-476.8 mbsf: Angular to subrounded clasts of intermediate to acid lava

\section{Mineralogical Composition}

Figure 7 shows the compositions of both the clay mineral fraction and the bulk sediment.

The $<2-\mu \mathrm{m}$-fractions of the Subunits IA and IB consist of an average of $60 \%$ smectite, the rest being equally divided between illite and kaolinite/chlorite. In the Subunit IC the only clay mineral present is smectite.

The bulk sediment contains less than $5 \%$ quartz and $10 \%$ feldspars in Subunits IA and IB. Subunit IC is marked by two layers containing palygorskite and phillipsite. Moreover, in Subunit IC there are traces of magnetite to be found. The X-ray amorphous fraction of the bulk sediment displays a tendency to decrease with increasing depth. A 


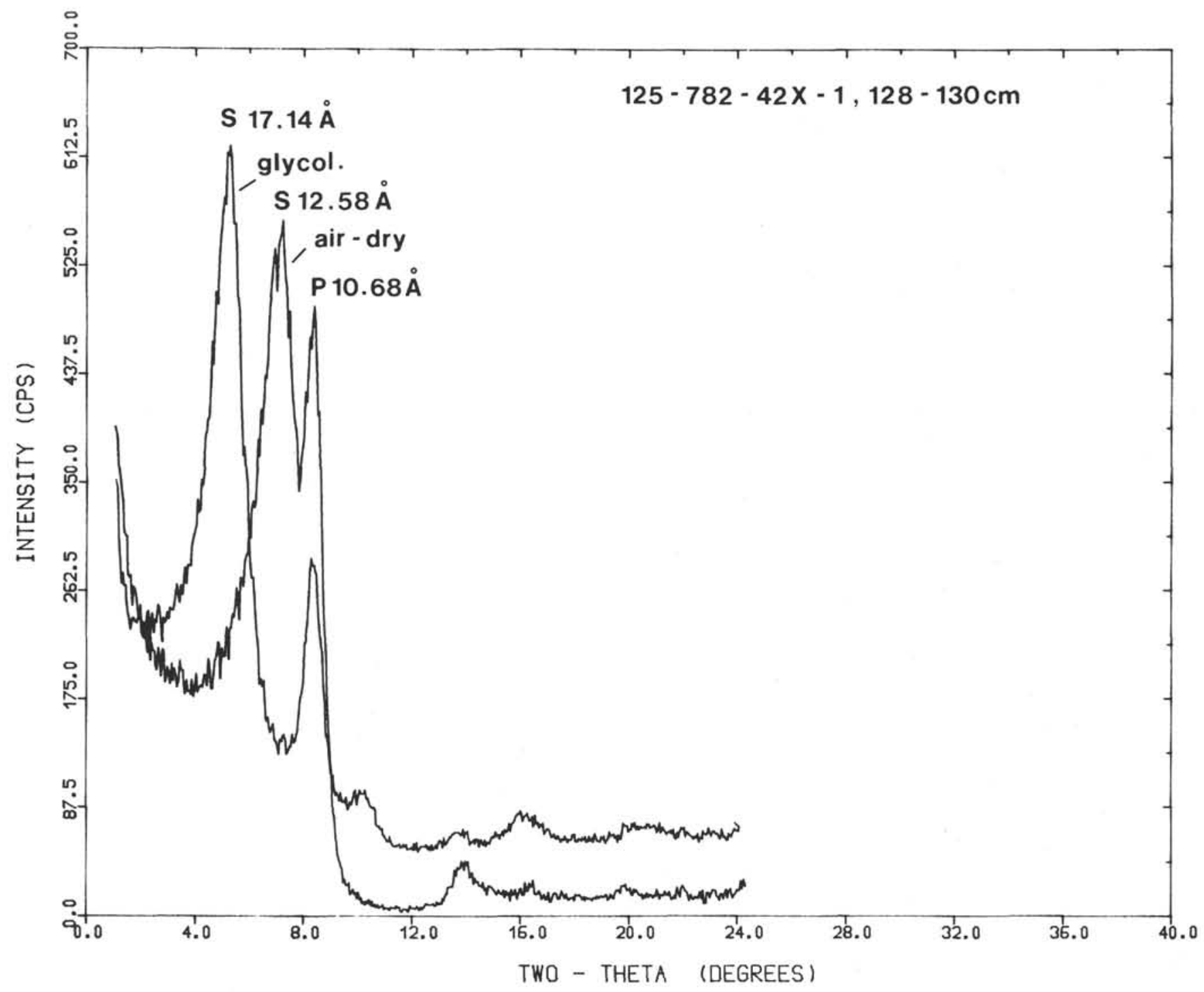

Figure 5. XRD patterns of a well-crystallized smectite and palygorskite, Site 782, Subunit IC, 391.1 mbsf.

similar trend shows the carbonate contents which decreases from approximately $50 \%$ at the top to approximately $10 \%$ at the bottom of the section.

The smectites found in the Subunits IA and IB seem to be different from the smectite of Subunit IC (see also Figs. 2-5). The position and shape of the first basal peak are as follows:

$\begin{array}{ll}\text { Subunits IA/IB } & \text { Subunit IC } \\ \mathrm{d}_{001} \text { air dry } 14.6 \AA & <13.5 \AA \\ \text { glycolated 16.6 } \\ \text { broad } & \begin{array}{l}17.5 \AA \\ \text { sharp }\end{array}\end{array}$

The smectite of Subunits IA and IB (Pleistocene-Miocene) seems to be a $\mathrm{Ca} / \mathrm{Mg}$-smectite of poor crystallographic order, whereas the smectite of Subunit IC (Oligocene-Eocene) appears to be a well ordered $\mathrm{Na}$-smectite.

Interestingly, palygorskite occurs, together with phillipsite and smectite in two thin horizons of Subunit IC.

\section{Chemical Analysis}

\section{Major Elements}

The major element composition of Sample 125-782-42X-2, 57-59 $\mathrm{cm}$ (391.9 mbsf, Subunit IC), $<2-\mu \mathrm{m}$-fraction, is smectite and phillipsite, yellowish-beige in color, shown in Table 1.

The composition of the analyzed sample is marked by a low $\mathrm{Al}$, a high $\mathrm{Fe}-$, and high $\mathrm{Ca}$ - content. According to the major element analyses, the smectite of Subunit IC belongs to the group of Fe-Al beidellites. The large abundance of $\mathrm{Ca}$ is due to some phillipsite and to some calcareous nannofossil ooze. A minor portion of $\mathrm{Ca}$ may be interlayered in the smectite, although the interlayer positions are likely to be occupied by $\mathrm{Na}$ because of the relative high Na-concentration.

\section{Trace Elements}

The trace element composition of the Samples 125-782-42X-2, $57-59 \mathrm{~cm}$, and $125-782-35 X-6,8-10 \mathrm{~cm}$, is shown in Table 2 and the REE profiles in Figure 11. 
Table 1. Major element concentrations of the clay fractions at Sites 782 and 784 and Hole $786 \mathrm{~B}$.

\begin{tabular}{|c|c|c|c|c|c|c|c|c|c|c|c|c|c|c|c|c|}
\hline \multirow[b]{2}{*}{ Samples } & \multirow[b]{2}{*}{$\begin{array}{l}\text { Depth } \\
{[\mathrm{m}]}\end{array}$} & \multicolumn{3}{|c|}{ Composition } & \multicolumn{12}{|c|}{ Major elements } \\
\hline & & $\begin{array}{l}\mathrm{Sm} \\
\%\end{array}$ & $\begin{array}{l}1 \\
\% \\
\end{array}$ & $\begin{array}{c}\mathrm{K} / \mathrm{C} \\
\% \\
\end{array}$ & $\begin{array}{c}\mathrm{SiO} 2 \\
\%\end{array}$ & $\begin{array}{c}\mathrm{MgO} \\
\%\end{array}$ & $\begin{array}{c}\mathrm{Na} 2 \mathrm{O} \\
\%\end{array}$ & $\begin{array}{c}\mathrm{Fe} 2 \mathrm{O} 3 \\
\%\end{array}$ & $\begin{array}{c}\mathrm{MnO} \\
\%\end{array}$ & $\begin{array}{c}\mathrm{TiO} 2 \\
\%\end{array}$ & $\begin{array}{c}\mathrm{P} 2 \mathrm{O} 5 \\
\%\end{array}$ & $\begin{array}{c}\mathrm{CaO} \\
\%\end{array}$ & $\begin{array}{c}\mathrm{K} 2 \mathrm{O} \\
\%\end{array}$ & $\begin{array}{c}\mathrm{Al} 2 \mathrm{O} 3 \\
\%\end{array}$ & $\begin{array}{c}\text { LOI } \\
\%\end{array}$ & $\begin{array}{c}\text { Total } \\
\%\end{array}$ \\
\hline $78235 X-6,8-10$ & 330,08 & \multirow{2}{*}{\multicolumn{3}{|c|}{$\begin{array}{l}\text { Sm + Palyg. } \\
100\end{array}$}} & \multicolumn{12}{|c|}{ not determined } \\
\hline $78242 X-2,57-59$ & 391,90 & & & & 43,30 & 4,66 & 3,90 & 8,11 & 0,18 & 0,46 & 0,05 & 10,7 & 1,12 & 8,19 & n.d. & 80,63 \\
\hline 784 1R-1, 29-31 & 0,29 & 59 & 19 & 22 & 55,95 & 3,46 & 1,37 & 9,93 & 0,23 & 0,79 & 0,13 & 1,17 & 2,98 & 16,64 & n.d. & 92,65 \\
\hline 784 3R-1, 97-99 & 11,87 & 74 & 11 & 15 & 57,66 & 3,72 & 1,24 & 10,06 & 0,25 & 0,69 & 0,09 & 1,18 & 3,09 & 15,79 & n.d. & 93,77 \\
\hline 784 4R-2, 74-76 & 22,64 & 86 & 7 & 7 & 56,85 & 3,68 & 1,35 & 12,40 & 0,31 & 0,70 & 0,16 & 1,03 & 3,00 & 14,74 & 8,44 & 102,66 \\
\hline 784 4R-4, 53-55 & 25,50 & 63 & 21 & 16 & 55,84 & 3,67 & 1,09 & 9,97 & 0,17 & 0,73 & 0,09 & 0,94 & 3,40 & 17,17 & 7,62 & 100,69 \\
\hline 784 6R-3, 115-117 & 43,60 & 68 & 16 & 16 & 57,27 & 3,56 & 1,35 & 8,97 & 0,27 & 0,72 & 0,10 & 1,13 & 3,07 & 16,08 & 8,08 & 100,60 \\
\hline $7847 R-1-3$ & $49-52$ & 68 & 14 & 18 & 55,60 & 3,36 & 0,81 & 8,73 & 0,20 & 0,63 & 0,11 & 2,27 & 2,85 & 15,20 & 9,90 & 99,66 \\
\hline 784 8R-3, 90-92 & 62,70 & 67 & 18 & 15 & 56,96 & 3,62 & 1,32 & 9,20 & 0,20 & 0,75 & 0,08 & 1,14 & 3,07 & 15,84 & n.d. & 92,18 \\
\hline 784 9R-4, 68-70 & 73,70 & 87 & 7 & 6 & 56,90 & 3,99 & 0,89 & 15,97 & 0,45 & 0,61 & 0,08 & 0,87 & 2,70 & 12,28 & 8,31 & 103,05 \\
\hline 784 11R-CC, 07-09 & 97,50 & 60 & 28 & 12 & 57,94 & 3,64 & 1,37 & 9,05 & 0,15 & 0,70 & 0,08 & 1,04 & 3,18 & 16,09 & n.d. & 93,45 \\
\hline 784 16R-5, 113-115 & 143,10 & 69 & 16 & 15 & 57,27 & 3,64 & 1,21 & 8,75 & 0,13 & 0,70 & 0,08 & 0,96 & 3,22 & 17,08 & 7,86 & 100,90 \\
\hline 784 17R-5, 60-62 & 152,20 & 89 & 6 & 5 & 58,04 & 3,30 & 1,75 & 9,02 & 0,18 & 0,78 & 0,11 & 2,92 & 1,96 & 16,29 & n.d. & 94,52 \\
\hline 784 18R-4, 48-50 & 160,30 & 87 & 9 & 4 & 58,79 & 3,43 & 1,21 & 10,18 & 0,16 & 0,71 & 0,07 & 0,92 & 3,16 & 14,21 & 7,42 & 100,26 \\
\hline 784 20R-3, 120-122 & 178,90 & 86 & 8 & 6 & 58,77 & 3,57 & 1,21 & 10,81 & 0,13 & 0,71 & 0,07 & 1,25 & 2,93 & 14,62 & n.d. & 94,29 \\
\hline 784 21R-2, 90-92 & 186,80 & 80 & 10 & 10 & 57,00 & 3,51 & 1,36 & 10,14 & 0,21 & 0,65 & 0,07 & 1,03 & 2,97 & 15,65 & 8,09 & 100,78 \\
\hline 784 22R-3, 105-107 & 198,10 & 76 & 12 & 12 & 58,19 & 3,41 & 0,95 & 8,64 & 0,70 & 0,70 & 0,62 & 1,89 & 3,17 & 15,99 & n.d. & 94,31 \\
\hline 784 23R-3, 65-67 & 207,30 & 84 & 8 & 8 & 58,74 & 3,37 & 1,21 & 9,62 & 0,15 & 0,66 & 0,07 & 0,95 & 3,17 & 15,97 & 8,52 & 102,43 \\
\hline 784 25R-1, 37-39 & 223,30 & 73 & 16 & 11 & 59,54 & 3,23 & 1,02 & 9,32 & 0,21 & 0,64 & 0,06 & 0,86 & 3,30 & 16,18 & n.d. & 94,62 \\
\hline 784 26R-2, 90-92 & 234,90 & 77 & 13 & 10 & 57,22 & 3,13 & 1,19 & 8,71 & 0,10 & 0,71 & 0,08 & 0,93 & 3,07 & 16,71 & n.d. & 92,09 \\
\hline 784 27R-5, 98-100 & 249,10 & 75 & 16 & 9 & 57,94 & 3,51 & 1,02 & 8,79 & 0,19 & 0,76 & 0,06 & 0,87 & 3,34 & 15,20 & n.d. & 91,92 \\
\hline 784 30R-1, 104-106 & 272,10 & 81 & 14 & 5 & 57,25 & 3,33 & 1,29 & 10,15 & 0,21 & 0,71 & 0,11 & 1,29 & 3,06 & 17,14 & n.d. & 94,78 \\
\hline 784 31R-1, 114-116 & 281,90 & 88 & 8 & 4 & 56,56 & 3,03 & 0,97 & 9,47 & 0,37 & 0,81 & 0,07 & 1,35 & 3,01 & 17,52 & n.d. & 93,42 \\
\hline 784 32R-1, 27-29 & 290,70 & 90 & 8 & 2 & 54,92 & 3,24 & 0,84 & 9,07 & 0,20 & 0,73 & 0,07 & 1,01 & 3,41 & 17,35 & n.d. & 91,05 \\
\hline 784 33R-3, 123-125 & 304,20 & 92 & 4 & 4 & 54,85 & 3,06 & 1,85 & 9,20 & 0,52 & 0,54 & 0,07 & 0,67 & 3,00 & 17,51 & 8,10 & 99,37 \\
\hline 784 33R-4, 02-04 & 304,55 & 91 & 7 & 2 & 54,69 & 3,10 & 1,16 & 11,76 & 0,50 & 0,68 & 0,09 & 0,74 & 3,67 & 19,18 & 6,99 & 102,66 \\
\hline 784 34R-1, 137-139 & 311,10 & 75 & 13 & 12 & 52,80 & 3,18 & 0,98 & 9,50 & 0,22 & 0,72 & 0,22 & 0,83 & 4,08 & 19,34 & 7,76 & 99,63 \\
\hline 786 22R-1, 30-32 & 362,92 & Sepioli & & & 60,24 & 24,6 & 0,28 & 0 & 0,88 & 0,03 & 0,01 & 0,13 & 0,06 & 2,79 & 11,5 & 100,53 \\
\hline 786 63R-1, 140-143 & 749,42 & 100 & & & 50,34 & 8,02 & 3,16 & 10,13 & 0,07 & 0,37 & 0,07 & 1,31 & 0,80 & 12,44 & n.d. & 86,71 \\
\hline
\end{tabular}

Very low concentrations of $\mathrm{Ce}, \mathrm{Nd}, \mathrm{Ba}, \mathrm{Cr}$, and $\mathrm{Rb}$ are noted. The REE profiles of these two samples show a significant negative cerium anomaly and a general depletion of the light rare earths, compared to common shales.

\section{Hole 783}

This site is located on the northern mid-flank of the same seamount as Hole 784. The cored section is divided into the following lithological units:

Unit

I $\quad 0-120.0$ mbsf: Glass-rich silty clay to claystone

II 120.0-158.6 mbsf: Phacoidal, sheared serpentine including clasts of serpentinized harzburgite

At this site, the cover of pyroclastic sediments and their alteration products is less than one-half the thickness of that in Hole 784.

\section{Mineralogical Composition}

The mineralogical composition of both the $<2 \mu \mathrm{m}$-fraction and the bulk sediment is shown graphically in Figure 8 . The $<2-\mu \mathrm{m}-$ fraction consists of $60 \%-80 \%$ smectite, $10 \%-30 \%$ illite and $10 \%$ to $20 \%$ kaolinite and chlorite. The smectite has poor crystallinity.

The bulk sediment is composed of $0 \%-5 \%$ quartz, $0 \%$ to nearly $20 \%$ of feldspars, some clinopyroxene and up to $20 \% \mathrm{CaCO}_{3}$ in a few horizons. In addition, the samples consist of considerable quantities of X-ray amorphous matter.

The color of most of the sediments is light grey. The sediments at this site seem to be identical with those recovered from Subunit IA at Site 784. No chemical analyses were performed on samples from Site 783 .

\section{Hole 784}

This site is located on the lowermost flank of a seamount that forms part of a long ridge, which runs along the inner wall of the Izu-Bonin Trench. The hole was drilled through the following lithological sections:

\section{Unit}

$$
\begin{aligned}
& \text { IA } \quad 0-126.4 \text { mbsf: Vitric clay and claystone } \\
& \text { IB } \quad 126.4-302.7 \text { mbsf: Vitric clayey silt and claystone } \\
& \text { IC } \quad 302.7-321.1 \text { mbsf: Claystone and silt-sized serpentine } \\
& \text { II } 321.1-425.3 \text { mbsf: Phacoidal sheared serpentine } \\
& \text { microbreccia }
\end{aligned}
$$

\section{Mineralogical Composition}

The mineralogical composition of both the $<2-\mu \mathrm{m}$-fraction and the bulk sediment is shown graphically in Figure 9 . The $<2-\mu \mathrm{m}$-fraction is composed of $60 \%-90 \%$ smectite, $5 \%-30 \%$ illite, and $5 \%-30 \%$ kaolinite and chlorite. 


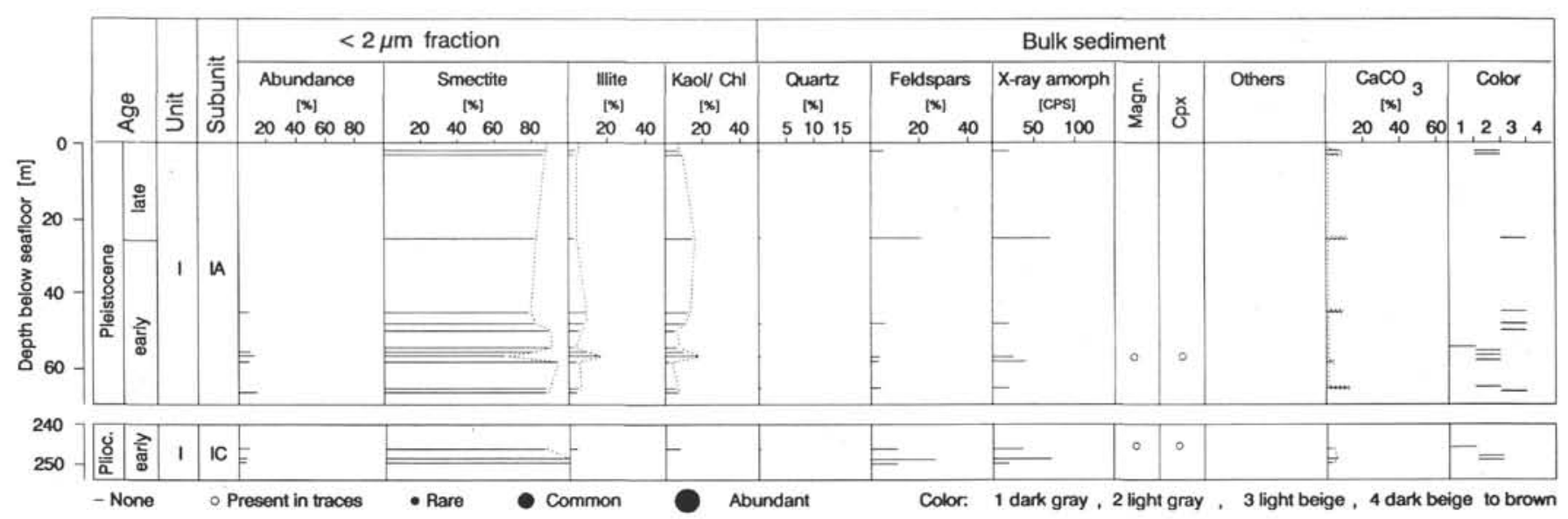

Figure 6. Mineralogical composition of sediments, Site 781.

The samples below 290 mbsf, particularly in Subunit IC, consist predominantly of smectite that displays a well-ordered crystallinity (Fig. 6), whereas the smectite of the overlying Subunits IA and IB has for the most part poor crystallinity (Fig. 5). In Subunit IC, the first basal spacing of the smectite drops from $>13.5 \AA$ to $<13.5 \AA$ (air dry).

The bulk sediment samples contain 5\%-10\% quartz and $10 \%-$ $20 \%$ feldspar, along with considerable portions of amorphous matter. Magnetite and traces of clinopyroxene are only found in Subunit IA and IB together with volcanic ash-layers. In Subunit IC these minerals as well as ash-layers are absent. The color of the sediments of Subunits IA and IB is mainly light gray, of Subunit IC light beige to brown.

\section{Chemical Analyses}

\section{Major Elements}

The major-element concentrations of samples from Sites 782, 784, and 786 are listed in Table 1.

The major-element concentrations of those samples consisting of more than $90 \%$ smectite are considered representative of the smectite mineral. Analyses of those samples confirm that the smectite is high in $\mathrm{Fe}$ and low in $\mathrm{Al}$.

There is no significant change in the composition of the $<2-\mu \mathrm{m}-$ fraction with increasing depth, particularly not between Subunits IA and IB. The trace element concentrations are listed in Table 2. High concentrations of $\mathrm{Ba}, \mathrm{Sr}, \mathrm{Zr}$, and $\mathrm{Rb}$ are noted.

The REE profiles of the clay fraction of Subunit IA and IB display more or less flat lines distinctively below the NAS average (North American Shale, Haskin and Haskin, 1966), but mostly with a slight depletion in cerium and a slight increase toward the heavy rare earths (Fig. 11, Sample 125-784-20R-3, 120-122 cm). The REE profiles of Subunit IC display flat lines very close to the NAS average, but always with a enrichment of cerium (Fig. 11, Sample 125-78434R-1, $98-100 \mathrm{~cm})$.

\section{Hole 786A}

This hole is located in the center of the Izu-Bonin forearc basin and was divided into four lithostratigraphic units.

\section{Unit}

I $\quad 0-83.46$ mbsf:Nannofossil marls and clays

II 83.46-103.25 mbsf: Nannofossil marls and clays together with vitric ash and mineral fragments

III 103.25-124.9 mbsf: Altered volcaniclastic breccia

IV $124.90-166.5$ mbsf: Volcaniclastic and sedimentary breccias and pyroclastic flows

\section{Mineralogical Composition}

The mineralogical composition of the sediments is shown in Figure 10. The section at Hole 786A is similar to that of Site 782. In Unit I nannofossil carbonate ooze is the major component of the sediment. Beside some carbonate, the clay fraction consists of smectite, illite, kaolinite, and chlorite in similar quantities as at Site 782.

From Unit II through Unit IV the only clay mineral present is smectite, which occurs together with phillipsite, carbonate, and some feldspars. This mineral assemblage is similar to that of Subunit IC at Site 782.

No chemical analyses were performed on samples from Hole $786 \mathrm{~A}$. Hole $786 \mathrm{~B}$ penetrated over $700 \mathrm{~m}$ into the massive, brecciated, and pillowed lavas and dikes of an Eocene volcano. Two samples were investigated. One sample (125-786B-63R-1, 140-143 cm) was taken from a dark green siltstone to claystone that is interlayered with igneous rocks at approximately $750 \mathrm{mbsf}$.

The bulk sample consists predominantly of smectite, clinoptilolite, and plagioclase, with amorphous matter present only in small quantities. The clay fraction consists of pure smectite, having high crystallographic order. The major element concentrations of this smectite are listed in Table 1, the trace element concentrations in Table 2, and the REE pattern in Figure 11.

The major element analyses are marked by high abundances of $\mathrm{Mg}$ and $\mathrm{Na}$ and relatively low $\mathrm{Al}$ and $\mathrm{Si}$. In comparison with the samples of Site 784, the trace element composition of this sample shows a depletion of $\mathrm{Ce}, \mathrm{Nd}, \mathrm{Cr}, \mathrm{Ni}, \mathrm{Cu}, \mathrm{Ba}$, and $\mathrm{Y}$. The chemical data are similar to those of the smectite separated from the sediments of Site 782 .

On the basis of an anion composition of $\mathrm{O}_{20}(\mathrm{OH})_{4}$, representing an anion charge of -44 , the following structural formula was calculated:

$$
\begin{gathered}
\left(\mathrm{Al}_{1.16}, \mathrm{Fe}_{1.10}, \mathrm{Mg}_{1.74}\right)\left(\mathrm{Si}_{7.31} \mathrm{Al}_{10.69}\right) \mathrm{O}_{20}(\mathrm{OH})_{4} \mathrm{Na}_{0.89} \mathrm{Ca}_{0.20} \mathrm{~K}_{t .15} \mathrm{Al}- \\
(\mathrm{OH})_{0.273}
\end{gathered}
$$

The formula was calculated by insertion of $\mathrm{Si}$ into the tetrahedral sites, with the remaining sites occupied by $\mathrm{Al}$. $\mathrm{Mg}$ and $\mathrm{Fe}$ were allocated into the octahedral sites. After occupation of the remaining octahedral positions by $\mathrm{Al}$, a surplus of $\mathrm{Al}$ remained. This $\mathrm{Al}$ was assumed to be amorphous interlayer Al-hydroxy impurities. The surplus of $\mathrm{Al}$, however, will be reduced if not all of the total iron is ferric $\left(\mathrm{Fe}^{\mathrm{III}}\right)$, as assumed for the calculation, but ferroan $\left(\mathrm{Fe}^{\mathrm{II}}\right)$. Unfortunately ferric and ferroan iron were not discriminated by the chemical analyses.

The assumption of interlayer $\mathrm{Al}$-hydroxy may be incorrect, as $\mathrm{Fe}$ and $\mathrm{Mg}$ may be incorporated in interlayer positions. Furthermore, some of the $\mathrm{Mg}$ may be included into the interlayers instead of occupying an octahedral position, thereby allowing more $\mathrm{Al}$ to enter 


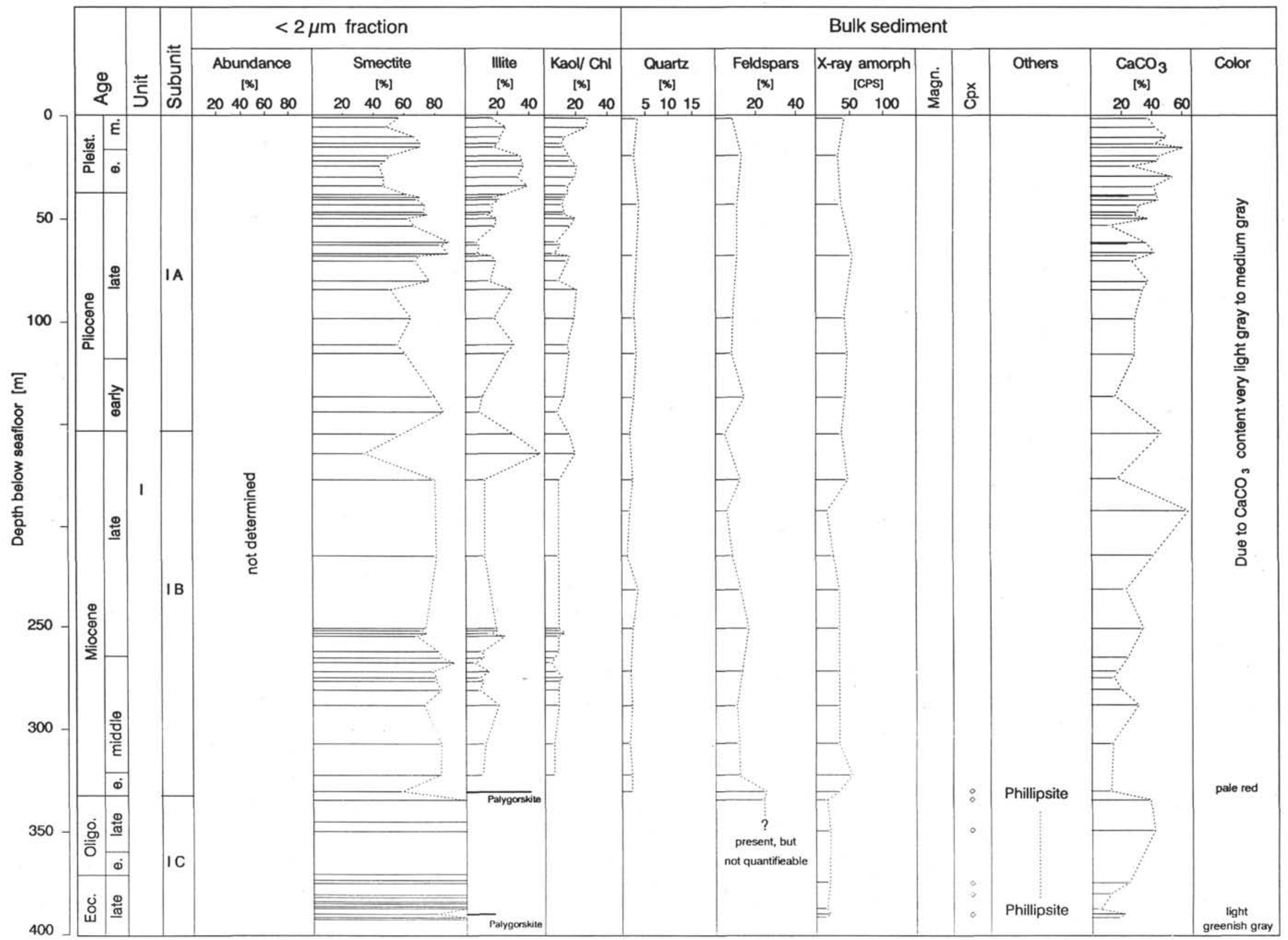


Table 2. Trace element concentrations of the clay fractions at Sites 782 and 784 and Hole $786 \mathrm{~B}$.

\begin{tabular}{|c|c|c|c|c|c|c|c|c|c|c|c|c|c|c|c|c|c|c|c|c|c|}
\hline \multirow[b]{2}{*}{ Samples } & \multicolumn{21}{|c|}{ Trace elements [ppm] } \\
\hline & $\mathrm{Sn}$ & Mo & $\mathrm{Nb}$ & $\mathrm{Zr}$ & $\mathrm{Y}$ & $\mathrm{Sr}$ & $\mathrm{Rb}$ & Th & $\mathrm{Pb}$ & $\mathrm{Zn}$ & Ta & $\mathrm{Hf}$ & $\mathrm{Ni}$ & Ga & $\mathrm{Cu}$ & $\mathrm{Cr}$ & Co & $\mathrm{Ba}$ & Cs & Sc & V \\
\hline $78235 X-6,8-10$ & & $<5$ & 8 & 105 & 37 & 221 & 113 & 6 & 18 & 219 & & $<5$ & 112 & 18 & 208 & 34 & 31 & 377 & 14 & 22 & \\
\hline $78242 X-2,57-59$ & 0 & 13 & $<5$ & 42 & 8 & 191 & 18 & 0 & 14 & 102 & 0 & $<5$ & 39 & 8 & 72 & 8 & 15 & 19 & $<5$ & 21 & 80 \\
\hline 784 1R-1, 29-31 & 4 & 8 & 18 & 102 & 30 & 145 & 99 & 14 & 41 & 199 & 3 & 6 & 84 & 32 & 97 & 87 & 23 & 1237 & 17 & 8 & 189 \\
\hline 784 3R-1, 97-99 & 3 & 9 & $<5$ & 90 & 19 & 118 & 97 & 14 & 37 & 251 & 3 & 3 & 69 & 28 & 53 & 72 & 38 & 1188 & 3 & 7 & 168 \\
\hline 784 4R-2, 74-76 & 3 & 9 & $<5$ & 77 & 25 & 137 & 95 & 2 & 35 & 155 & 0 & 4 & 51 & 32 & 159 & 69 & 36 & 1015 & 8 & 5 & 209 \\
\hline 784 4R-4, 53-55 & 4 & 7 & 14 & 95 & 27 & 125 & 118 & 9 & 55 & 229 & 1 & 3 & 70 & 17 & 64 & 92 & 20 & 988 & 4 & 7 & 164 \\
\hline 784 6R-3, 115-117 & 4 & 10 & $<5$ & 93 & 25 & 135 & 98 & 15 & 128 & 254 & 1 & 5 & 52 & 29 & 116 & 83 & 27 & 1199 & 13 & 7 & 165 \\
\hline 784 7R-1-3 & 7 & 13 & 7 & 75 & 12 & 101 & 77 & 5 & 45 & 179 & 3 & 5 & 52 & 19 & 170 & 31 & 30 & 764 & 6 & 19 & 100 \\
\hline 784 8R-3, 90-92 & 2 & 8 & 13 & 68 & 22 & 98 & 80 & 7 & 26 & 211 & 3 & 4 & 82 & 29 & 82 & 90 & 31 & 971 & 5 & 12 & 168 \\
\hline 784 9R-4, 68-70 & 3 & 11 & 21 & 71 & 20 & 111 & 86 & 1 & 33 & 178 & 3 & 4 & 108 & 21 & 170 & 66 & 97 & 843 & 4 & 8 & 239 \\
\hline 784 11R-CC, 07-09 & 4 & 8 & $<5$ & 85 & 31 & 118 & 92 & 8 & 31 & 184 & 0 & 5 & 53 & 25 & 60 & 71 & 20 & 1038 & 4 & 5 & 162 \\
\hline 784 16R-5, 113-115 & 4 & 8 & 20 & 87 & 27 & 105 & 117 & 6 & 55 & 174 & 2 & 6 & 53 & 31 & 80 & 99 & 11 & 733 & 15 & 21 & 149 \\
\hline 784 17R-5, 60-62 & 3 & 15 & 7 & 65 & 32 & 131 & 53 & 4 & 65 & 228 & 1 & 2 & 62 & 27 & 128 & 57 & 28 & 570 & 3 & 10 & 181 \\
\hline 784 18R-4, $48-50$ & 4 & 7 & 8 & 97 & 30 & 103 & 107 & 2 & 21 & 142 & 2 & 8 & 44 & 37 & 231 & 79 & 18 & 744 & 7 & 10 & 166 \\
\hline 784 20R-3, 120-122 & 3 & 9 & 5 & 69 & 17 & 104 & 95 & 5 & 36 & 163 & 1 & 4 & 55 & 29 & 53 & 62 & 40 & 1155 & 8 & 16 & 187 \\
\hline 784 21R-2, 90-92 & 4 & 10 & $<5$ & 73 & 25 & 121 & 85 & 13 & 26 & 186 & 0 & 3 & 48 & 20 & 98 & 54 & 20 & 1471 & 4 & 4 & 165 \\
\hline 784 22R-3, 105-107 & 3 & 8 & 24 & 73 & 32 & 129 & 102 & 13 & 42 & 179 & 3 & 3 & 60 & 32 & 75 & 86 & 19 & 1129 & 12 & 10 & 154 \\
\hline 784 23R-3, 65-67 & 3 & 8 & 3 & 79 & 17 & 121 & 104 & 7 & 59 & 145 & 0 & 4 & 50 & 34 & 77 & 70 & 16 & 1154 & 3 & 10 & 157 \\
\hline 784 25R-1, 37-39 & 4 & 8 & 10 & 85 & 23 & 127 & 119 & 7 & 34 & 149 & 4 & 4 & 76 & 32 & 118 & 79 & 25 & 1368 & 1 & 6 & 152 \\
\hline 784 26R-2, 90-92 & 3 & 8 & 14 & 84 & 30 & 107 & 107 & 8 & 28 & 152 & 2 & 4 & 63 & 32 & 116 & 88 & 19 & 1332 & 2 & 9 & 161 \\
\hline 784 27R-5, 98-100 & 4 & 7 & 11 & 87 & 12 & 112 & 122 & 2 & 54 & 162 & 6 & 3 & 54 & 32 & 174 & 83 & 31 & 1284 & 25 & 14 & 154 \\
\hline 784 30R-1, 104-106 & 3 & 9 & $<5$ & 71 & 17 & 125 & 104 & 4 & 68 & 159 & 2 & 3 & 56 & 27 & 148 & 65 & 27 & 1386 & 9 & 5 & 176 \\
\hline 784 31R-1, 114-116 & 4 & 8 & 13 & 96 & 29 & 124 & 111 & $<5$ & 39 & 168 & 2 & 7 & 66 & 38 & 528 & 92 & 21 & 1047 & 8 & 8 & 171 \\
\hline 784 32R-1, 27-29 & 5 & 7 & $<5$ & 104 & 25 & 110 & 132 & 7 & 39 & 159 & 3 & 9 & 69 & 36 & 101 & 84 & 29 & 966 & 7 & 14 & 153 \\
\hline 784 33R-3, 123-125 & 5 & 9 & 5 & 97 & 12 & 77 & 97 & 8 & 34 & 111 & 5 & 5 & 42 & 20 & 154 & 22 & 21 & 261 & 9 & 15 & 98 \\
\hline 784 33R-2, $02-04$ & 5 & 6 & 14 & 112 & 27 & 93 & 135 & 11 & 73 & 143 & 6 & 2 & 59 & 46 & 91 & 85 & 10 & 373 & 11 & 9 & 191 \\
\hline 784 34R-1, 137-139 & 5 & 4 & 15 & 119 & 27 & 87 & 157 & 11 & 54 & 158 & 5 & 7 & 78 & 32 & 141 & 85 & 34 & 540 & 10 & 4 & 154 \\
\hline 786B 22R-1, 30-32 & & & $<5$ & 7 & $<5$ & 100 & $<5$ & $<5$ & $<5$ & 205 & & $<5$ & 383 & $<5$ & 313 & 6 & 88 & 1272 & $<5$ & $<5$ & \\
\hline 786B 63R-1, 140-143 & 14 & 14 & $<5$ & 71 & 8 & 51 & 9 & 0 & 8 & 115 & $<5$ & $<5$ & 22 & 19 & 39 & 5 & 27 & 24 & 6 & 25 & 83 \\
\hline
\end{tabular}

octahedral sites. However, the $(060)$ peak of the analyzed smectite at $1.515 \AA$ indicates that the mineral is not purely dioctahedral. Nevertheless, it is designated an iron- and magnesium-rich beidellite.

The shale-normalized REE profile shows a heavy depletion of the light rare earths, but no distinct cerium deficiency with respect to $\mathrm{La}$, $\mathrm{Pr}$, and Nd.

Another sample (125-786B-22R-1,30-32 cm) was taken from a sandstone, which is interlayered between a dacite breccia and a basalt flow. XRD analyses show that the whole sample consists of pure sepiolite. The color of the sample is pink.

The major element analyses of the clay fraction is listed in Table 1. The sample consists mainly of $\mathrm{Si}$ and $\mathrm{Mg}$ and does not contain any iron. The small amounts of Al could be due to the presence of some palygorskite, which could not be detected by XRD analyses. The trace element composition is listed in Table 2. High concentrations of $\mathrm{Ni}$, $\mathrm{Cu}, \mathrm{Zn}$, and $\mathrm{Ba}$ are noted.

The chondrite-normalized REE profile is shown in Figure 11. All rare earths are depleted with the exception of europium, which displays a positive anomaly.

\section{Summary of Results}

In Table 3 the results of the mineralogical analyses of both the bulk samples and the $<2-\mu \mathrm{m}$ fraction are summarized. The numbers are average percentages for each subunit. The variations of some major cation concentrations of the pore solutions (Fryer et al., 1990) are included in the table.
The chemical analyses of the $<2-\mu \mathrm{m}$ fraction from Site 784 , averaged for the different subunits, are listed in Table 4.

\section{DISCUSSION}

Smectite is the prevailing mineral of the clay fractions of all samples investigated from Leg 125 sites. Illite, kaolinite, and chlorite are minor components, in some sections they are completely lacking. As there are no signs that any of these clay minerals increase significantly in abundance with increasing depth, they are considered to be of detrital origin. Since a detrital portion has certainly contributed to the clay fraction it is probable that at least part of the smectite, where it is accompanied by illite, kaolinite, and chlorite, was derived in this way.

The chemical composition of clay fractions from Site 784 samples, containing prevailingly smectite, indicate that the smectite belongs to the high $\mathrm{Fe}$ - and low $\mathrm{Mg}$-beidellite group. In contrast, smectites from Subunit IC at Site 782 and from Hole 786B are higher in $\mathrm{Mg}$ and lower in octahedral Al. Therefore the latter smectites are assigned to the high $\mathrm{Mg}$-beidellite group.

Many ash layers are included in the sections drilled, particular those of Site 782 and 784. All the major elements necessary to form beidellitic smectite, in particular $\mathrm{Fe}, \mathrm{Mg}$, and $\mathrm{Al}$, may have been derived from the glass by halmyrolysis. Above all, silica might be derived from the glass, however, this may also have been supplied from radiolarians, diatoms, spicules, and silicoflagellates. All of these microfossils were found to be abundant in the cored sections and thus could provide silica for extensive in situ formation of smectite. 


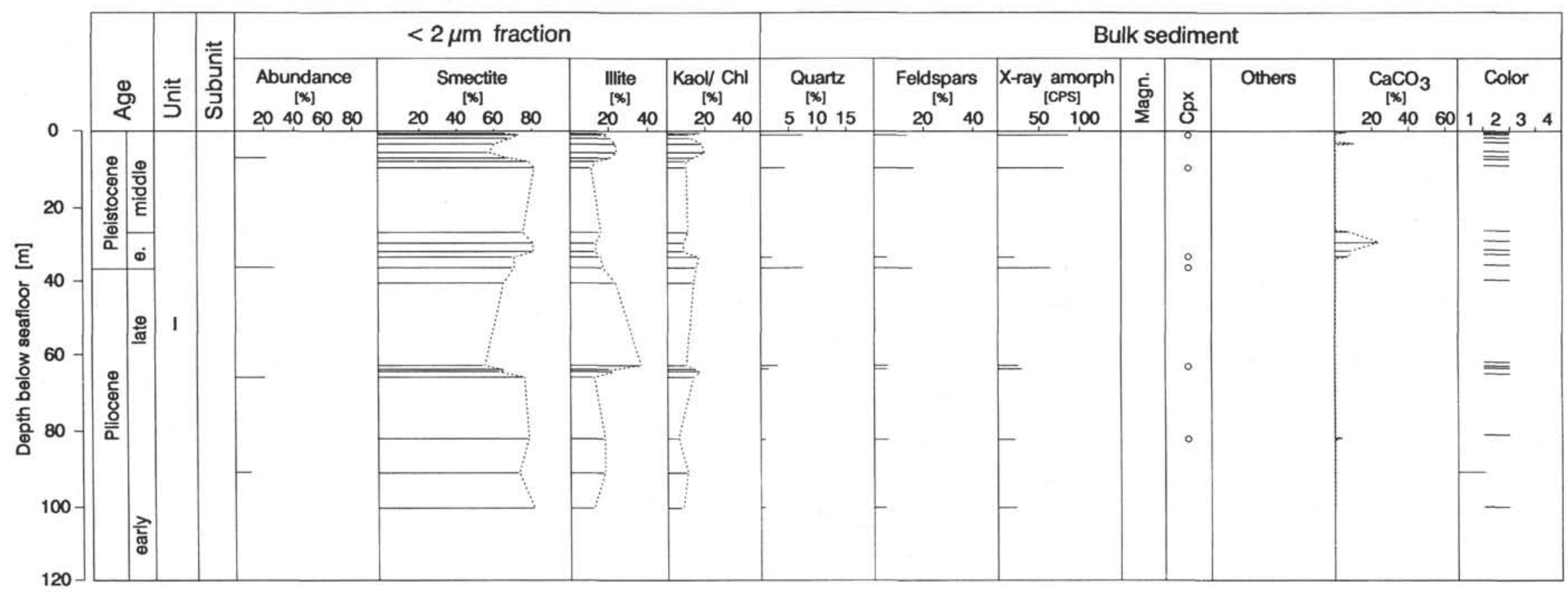

Figure 8. Mineralogical composition of sediments, Site 783. 


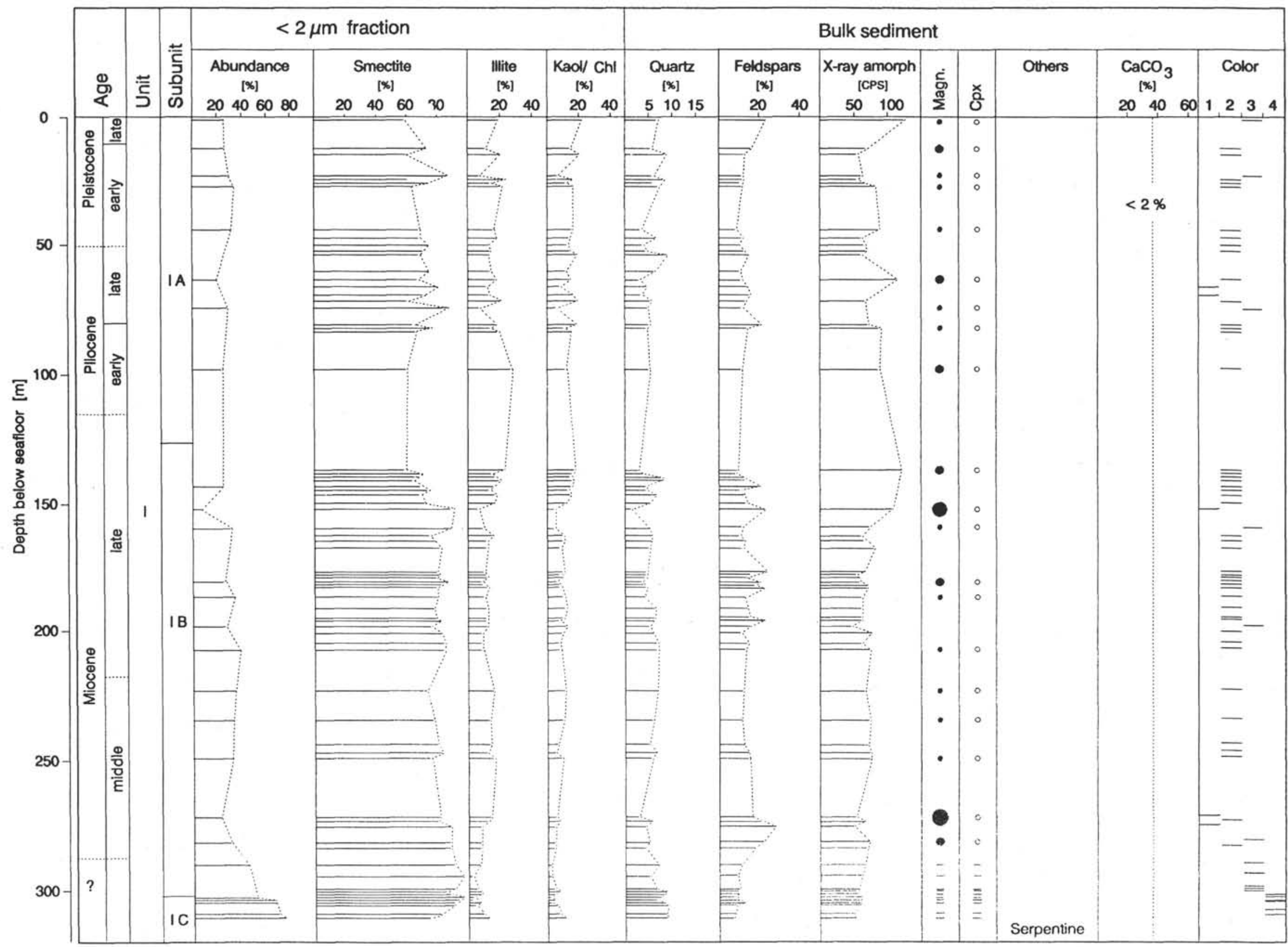




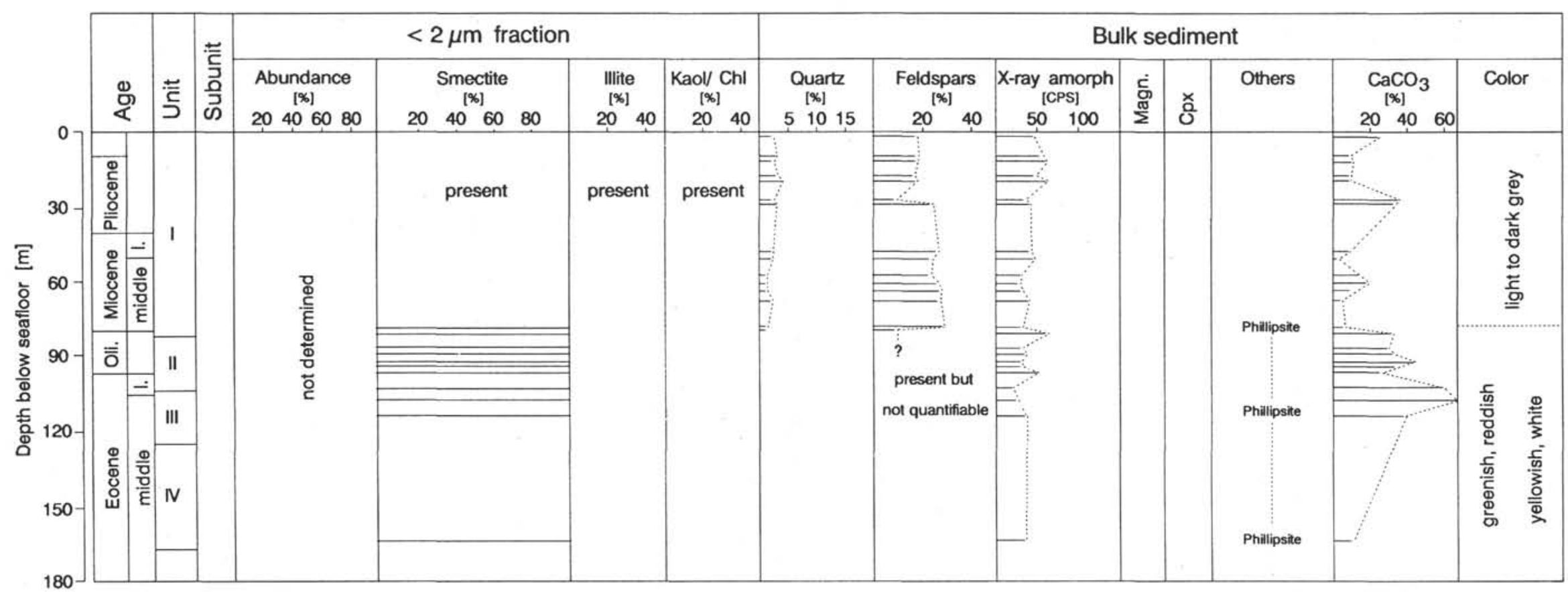

Figure 10. Mineralogical composition of sediments, Hole 786A. 

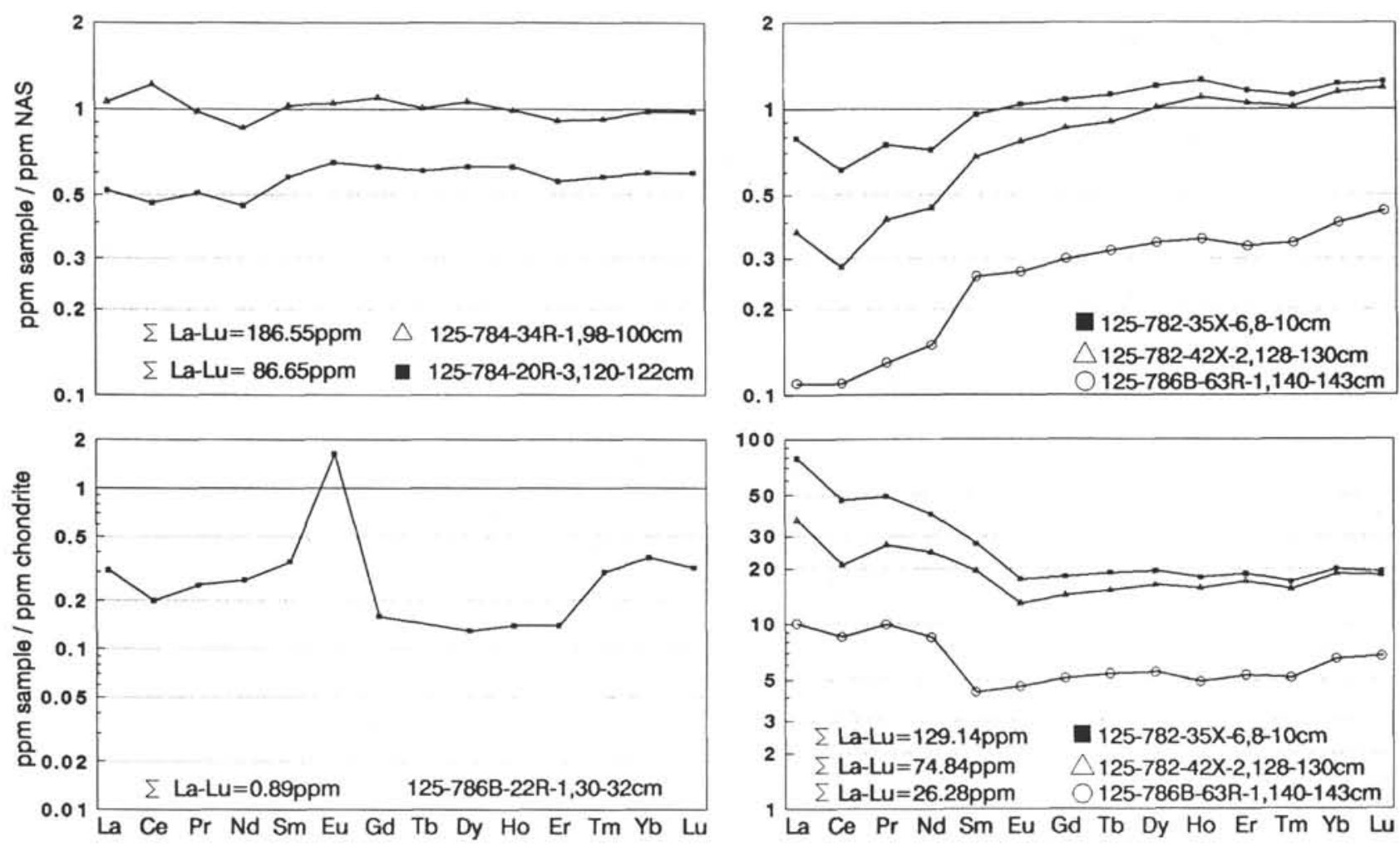

Figure 11. REE distributions of the clay fractions from Sites 782 and 784 and Hole 786B.

In slope sediments from offshore Guatemala and Costa Rica, Helm (1984) observed etching features on opal-A skeletons and concluded that dissolution of siliceous biogenic matter is the main source of silica for early diagenesis of smectite.

Did smectite form in the pre-burial or in the shallow-burial stage of the post-depositional history of the sediment? The change in composition of the interstitial solutions may answer this question. In most sections, silica and $\mathrm{Ca}^{2+}$ increase, while $\mathrm{Mg}^{2+}, \mathrm{K}^{+}$, and $\mathrm{Na}^{+}$ decrease with increasing depth. This increase in silica most likely was caused by a dissolution of either organic silica or volcanic glass. If the dissolution exceeded the possible simultaneous consumption of silica for the formation of smectite in shallow-burial diagenesis, the net effect would be an increase of silica with depth, as observed in the upper subunits. Because an exchange with seawater is most readily accomplished on the seafloor, the bulk of the smectite authigenesis is thought to have occurred on the seafloor.

We should mention that in Site 781, in contrast to Sites 782 and 784 , the silica concentration in the pore water decreases with depth, which corresponds with a decrease in the abundance of biogenic silica in the bulk sediments. This correspondence suggests that silica is more readily supplied by biogenic sources than by volcanic glass (Helm, 1984). Although silica may be the controlling factor one should not neglect that $\mathrm{Al}$ and $\mathrm{Fe}$ also is needed for the formation of smectite, and these elements might easily be derived from volcanic glass.

As for the illite (found in the clay fractions), no increase of illite occurred at the expense of smectite with depth, as it is typically found in many diagenetic sections. Obviously, the temperature increase in the depth range, penetrated by the drill holes, is not great enough to transform smectite to illite. Although the $\mathrm{K}^{+}$-concentrations of the interstitial solutions in all four examined sections decrease with increasing depth, no corresponding transformation of the smectite to illite could be detected by an increase in abundance of illite. Thus the illite of all drilled sites can be considered to be a detrital component.

Rare earth element (REE) profiles of submarine smectites have been quoted to discriminate between hydrogenous and detrital smec- tites (Piper, 1974). In particular, a negative Ce-anomaly, is considered to indicate a hydrogenous origin, because seawater is deficient in $\mathrm{Ce}$ as a result of being readily adsorbed by manganese nodules, as well as precipitated by Fe-flocculation on the seafloor. Twenty-one samples of the clay fraction were analyzed for their REE content. Four different types of NAS-normalized REE profiles were distinguished.

Type one (Fig. 11, Sample 125-784-34R-1, 98-100 cm) displays a flat line very close to the NAS standard and always shows a Ce enrichment. This REE profile is characteristic for the clay fraction of Subunit IC at Site 784, but sometimes also occurs in the upper subunits (IA, IB). Since those profiles are typical for terrigenous sediments, the clay fraction of Subunit IC at Site 784 is assumed to be exclusively of detrital origin.

Type two (Fig. 11, Sample 125-784-20R-3, 120-122 cm) also displays a more or less flat line, which runs, however, always distinctively below the NAS standard. Furthermore, a slight depletion of Ce, with respect to $\mathrm{La}, \mathrm{Pr}$, and $\mathrm{Nd}$ and a slight increase toward the heavy rare earths is observed. These REE profiles are common in Subunits IA and IB at Site 784. They probably reflect a mixture of authigenic (Ce-depleted) and detrital (Ce-enriched) components (Tlig, 1981). Therefore the smectites of the upper subunits at Site 784 are considered to have two different origins. An authigenic component, derived from volcanic glass, radiolarians, and diatoms, and a detrital component derived from continental debris.

Type three (Fig. 11, Samples 125-782-35X-6, 8-10 cm, and $125-782-42 X-2,128-130 \mathrm{~cm}$ ) display a significant negative Ce anomaly and a steep increase toward the heavy rare earths. All together the light rare earths are depleted. When chondrite-normalized, the profiles are very similar in shape as well as concentration to those of basalts.

Type three is characteristic for the clay fractions of Subunit IC at Site 782. There, smectite occurs together with phillipsite and palygorskite above an underlying basalt. All the three minerals are considered to have evolved authigenically from basalt under unrestricted influence of seawater. 
Table 3. Summary of mineralogical data, in relation to pore solution chemistry. (The numbers are average for each subunit.)

\begin{tabular}{|c|c|c|c|c|c|c|c|c|c|c|c|c|c|}
\hline \multirow[b]{2}{*}{ Site } & \multirow[b]{2}{*}{ Unit } & \multicolumn{3}{|c|}{$<2 \mu$ m fraction } & \multicolumn{4}{|c|}{ Bulk sample } & \multicolumn{5}{|c|}{ Pore solutions } \\
\hline & & $\begin{array}{l}\mathrm{Sm} \\
{[\%]}\end{array}$ & $\begin{array}{c}1 \\
{[\%]}\end{array}$ & $\begin{array}{l}K / C \\
{[\%]}\end{array}$ & $\begin{array}{l}\text { Quartz } \\
\text { [\%] }\end{array}$ & $\begin{array}{l}\text { Fsp } \\
\text { [\%] }\end{array}$ & $\begin{array}{l}\text { amorph } \\
\text { [cps] }\end{array}$ & $\begin{array}{c}\mathrm{CaCO}_{3} \\
{[\%]}\end{array}$ & Silica & $\mathrm{Ca}^{2+}$ & $\mathrm{Mg}^{2+}$ & $\mathrm{K}^{+}$ & $\mathrm{Na}^{+}$ \\
\hline \multirow{3}{*}{781} & IA & 85 & 06 & 09 & 01 & 07 & 32 & 05 & decr. & incr. & decr. & decr. & no ch. \\
\hline & IB & ? & $?$ & $?$ & $?$ & $?$ & $?$ & $?$ & no ch. & incr. & decr. & decr. & no ch. \\
\hline & IC & 96 & 01 & 03 & 00 & 16 & 40 & 03 & $?$ & $?$ & $?$ & ? & $?$ \\
\hline \multirow{3}{*}{782} & IA & 62 & 21 & 17 & 03 & 09 & 39 & 34 & incr. & no ch. & decr. & decr. & no ch. \\
\hline & IB & 76 & 15 & 09 & 04 & 11 & 33 & 25 & incr. & incr. & decr. & decr. & no ch. \\
\hline & IC & 100 & $\infty$ & $\infty$ & 00 & 32 & 20 & 21 & decr. & incr. & decr. & decr. & no ch. \\
\hline 783 & IA & 68 & 19 & 13 & 04 & 09 & 45 & 03 & decr. & incr. & decr. & decr. & incr. \\
\hline \multirow{3}{*}{784} & IA & 70 & 16 & 14 & 05 & 13 & 74 & $<2$ & incr. & incr. & decr. & decr. & no ch. \\
\hline & IB & 80 & 11 & 09 & 05 & 14 & 66 & $<2$ & incr. & incr. & decr. & decr. & no ch. \\
\hline & IC & 88 & 07 & 05 & 09 & 09 & 58 & $<2$ & decr. & incr. & decr. & decr. & decr. \\
\hline
\end{tabular}

Type four (Fig. 11, Sample 125-786-63R-1, 140-143 cm) does not show a Ce depletion with respect to $\mathrm{La}, \mathrm{Pr}$, and $\mathrm{Nd}$, but is in general heavily depleted in all light rare earth elements (compared to NAS) and increases toward the heavy ones. When chondrite-normalized, these samples also display a line which is similar to those of basalts, but the REE concentrations are distinctively lower. The clay fraction of these samples consists exclusively of smectite which is assumed to have evolved from hyaloclastites or vitric tuffs under restricted contact with seawater. Therefore, the REE content might be inherited from the initial rock.

Sepiolite displays, when normalized to chondrites (Fig. 11, 125$786 \mathrm{~B}-22 \mathrm{R}-1,30-32 \mathrm{~cm}$ ), a heavy depletion of all rare earth elements, with the exception of europium, where a positive anomaly is observed. This REE profile, as well as the high concentrations of Ni, $\mathrm{Cu}$, and $\mathrm{Zn}$, leads to the conclusion that this mineral might have formed from direct precipitation from hydrothermal solutions.

The crystallinity of hydrogenous smectites is normally higher than that of detrital types. This holds true for the smectites found in the lower units of Sites 782 and 786, which are assumed to have formed hydrogenously. The smectites at Site 784 , where authigenic and detrital types have mixed (Subunit IA and IB), display a surprisingly very low crystallinity, whereas the smectites of the underlying Subunit IC, which are assumed to be exclusively of detrital origin, display a high crystallographic order (see also Figs. 2-5).

Some scattered palygorskite that deserves special attention was found in Subunit IC of Site 782. Desprairies (1982) found palygorskite (attapulgite) at DSDP Site 460 (780 mi south of Site 782, Leg 125) on the eastern deep flank of the Mariana Ridge in middle and late Oligocene sediments. This is the same stratigraphic position where palygorskite was found in Site 782. Desprairies is interpreted to indicate that palygorskite have formed hydrogeneously, supported by hydrothermal activity in the igneous basement. The same is probably true for the origin of the palygorskite found in Site 782. The REE profile of Sample 125-782-35X-6, 8-10 cm, also gives support to this consideration. A detrital supply, as considered for many occurrences of palygorskite in the Pacific Ocean (Lenotre, 1985; Chamley, 1989), seems unlikely in this case.

Near Site 782, Natland and Mahoney (1982; DSDP Sites 458 and 459) found palygorskite at a position stratigraphically similar to the palygorskite of Site 782. This palygorskite (along with dioctahedral smectites and Fe-hydroxides) occurred as vein fillings in basalts. The authors considered this palygorskite to have evolved from smectite at places where $\mathrm{Mg}$ and silica were highly concentrated. The smectite was presumed to have formed hydrogeneously.

\section{CONCLUSIONS}

Our results and discussion led to the following conclusions:

1. The $<2-\mu \mathrm{m}$-fractions of the Mariana and Izu-Bonin forearc sediments recovered during Leg 125 consist predominantly of smectite, along with minor portions of illite, kaolinite, and chlorite.

2. Smectite at Site 784 is a Fe-rich and relatively Mg-poor beidellite, of which one type is poorly crystallized and characterized by a slight $\mathrm{Ce}$ deficiency, and the other type is well-crystallized and displays a Ce enrichment, compared to common shales. The poorly crystallized type is assumed to represent a mixture of allochthonous and autochthonous smectites, the well-crystallized one is thought to be exclusively of detrital origin, also supported by the fact that no volcaniclastics were found in these strata. Smectites occurring above underlying basalts at Site 782 and Hole 786A show a high negative $\mathrm{Ce}$ anomaly and high crystallinity. Therefore, they are considered to 
Table 4. Average major element concentrations of the clay fraction at Site 784.

\begin{tabular}{|c|c|c|c|}
\hline Unit & IA & IB & IC \\
\hline $\mathrm{SiO}_{2} \quad[\%]$ & 56.77 & 57.71 & 54.11 \\
\hline $\mathrm{Al}_{2} \mathrm{O}_{3} \quad[\%]$ & 15.53 & 16.15 & 18.67 \\
\hline $\mathrm{Fe}_{2} \mathrm{O}_{3} \quad[\%]$ & 10.47 & 9.43 & 10.15 \\
\hline $\mathrm{MgO} \quad[\%]$ & 3.ஐ & 3.36 & 3.11 \\
\hline $\mathrm{CaO} \quad[\%]$ & 1.19 & 1.25 & 0.75 \\
\hline $\mathrm{K}_{2} \mathrm{O}$ [\%] & 3.03 & 3.06 & 3.58 \\
\hline $\mathrm{Na}_{2} \mathrm{O} \quad[\%]$ & 1.19 & 1.17 & 1.33 \\
\hline $\mathrm{MnO}$ & 0.25 & 0.22 & 0.41 \\
\hline $\mathrm{TiO}_{2}$ & 0.70 & 0.71 & 0.65 \\
\hline $\mathrm{P}_{2} \mathrm{O}_{5} \quad[\%]$ & 0.10 & 0.12 & 0.12 \\
\hline
\end{tabular}

have formed authigenously from the igneous basement by unrestricted contact with seawater. Smectites within hyaloclastites at Hole 786B have formed in situ, probably under restricted contact with seawater and are therefore not depleted in $\mathrm{Ce}$, with respect to $\mathrm{La}, \mathrm{Pr}$, and $\mathrm{Nd}$.

3. The sepiolite, which occurs at Hole 786B, is considered to have formed by direct precipitation from hydrothermal solutions.

4. Illite, kaolinite, and chlorite are probably detrital constituents. Indications of diagenetic neoformations or alterations are absent, probably because these sections did not exceed the shallow burial depth.

5 . The silica necessary for the formation of authigenous smectite probably derived from the dissolution of siliceous microfossils and of volcanic glass, both of which occurred abundantly in the inves- tigated sediments. Above the underlying basalt we favor the authigenic, hydrothermal formation of smectite. Subunit IC, Site 782, and Hole $786 \mathrm{~A}$ reflect this situation.

\section{ACKNOWLEDGMENTS}

The financial support of Deutsche Forschungsgemeinschaft through grant He 532/9-1, which made this study possible, is gratefully acknowledged.

By reviewing, Audrey Meyer and Warren Huff added considerably to the comprehensiveness of the paper.

\section{REFERENCES}

Chamley, H., 1989. Clay Sedimentology: Heidelberg (Springer Verlag).

Desprairies, A., 1982. Authigenic minerals in volcanogenic sediments cored during DSDP Leg 60. In Hussong, D. M., Uyeda, S., et al., Init. Repts. DSDP, 60: Washington (U.S. Govt. Printing Office), 455-466.

Fryer, P., Pearce, J. A., Stokking, L. B., et al., 1990. Proc. ODP, Init. Repts., 125: College Station, TX (Ocean Drilling Program).

Haskin, M. A., and Haskin, L. A., 1966. Rare earths in european shales: a redetermination. Science, 154:507-509.

Helm, R., 1984. Mineralogy and diagenesis of slope sediments offshore Guatemala and Costa Rica, DSDP Leg 84. In von Huene, R., Aubouin, J., et al., Init. Repts. DSDP, 84: Washington (U.S. Govt. Printing Office), 571-594.

Lenotre, N., Chamley, H., Hoffert, M., 1985. Clay stratigraphy at DSDP sites 576 and 578, Leg 86 (Western North Pacific). In Heath, G. R., Burckle, L. H., et al., Init. Repts. DSDP, 86: Washington (U.S. Govt. Printing Office), 571-579.

Müller, G., and Gastner, M., 1971. The "Karbonat-bombe:" a simple device for determination of the carbonate content in sediments, soils and other materials. Neues. Jahrb. Mineral. Monatsh., 10:466-469.

Natland, J. H., and Mahoney, J. J., 1982. Alteration in igneous rocks at DSDP sites 458 and 459 , Mariana fore arc region relationship to basement structures. In Hussong, D. M., Uyeda, S., et al., Init. Repts. DSDP, 60: Washington (U.S. Govt. Printing Office), 769-788.

Piper, D. Z., 1974. Rare earth elements in ferromanganese nodules and other marine phases. Geochim. Cosmochim. Acta, 38:1007-1022.

Tlig, S., and Steinberg, M., 1982. Distribution of rare-earth elements (REE) in size fractions of recent sediments of the Indian Ocean. Chem. Geol., 37:317-333.

Date of initial receipt: 1 October 1990

Date of acceptance: 6 May 1991

Ms 125B-147 